\title{
Effect of Different Regions and Ensiling Periods on Fermentation Quality and the Bacterial Community of Whole-Plant Maize Silage
}

\author{
Yuan Huang, Longfei Liang, Sheng Dai, Changrong Wu, Chao Chen and Jun Hao*
}

Department of Grassland Science, College of Animal Science, Guizhou University, Guiyang, China

This study aimed to explore the changes in the microbial community on the silage material surface and during the ensiling process of whole-plant maize in different regions. Whole-plant maize silages were sampled in Ziyun, Guanling, and Weinning counties within warm and humid climate areas in southern China. Silages were sampled at 0 , 2, 5, 10, 20, and 45 days during ensiling. The nutritional components, fermentation properties, and microbiomes were examined to evaluate the influence of sampling area and fermentation time on the quality of silage. The results showed that the $\mathrm{pH}$ values of all silages significantly decreased ( $<4.2$ at ensiling day 2$)$ during fermentation and all silages achieved satisfactory fermentation at 45 days. Butyric acid was not detected during ensiling, and the contents of acetic acid and ammonia nitrogen in the final silages were below $6 \mathrm{~g} / \mathrm{kg} \mathrm{DM}$ and $50 \mathrm{~g} / \mathrm{kg}$ total nitrogen, respectively. Weissella was the dominant epiphytic bacteria of raw material in Ziyun and Weinning, while Lactobacillus was prevalent in Guanling. Lactobacillus dominated the ensiling process, and its abundance significantly increased with increasing fermentation time in the three groups. Lactobacillus was negatively correlated with $\mathrm{pH}$ of all silages $(p<0.05)$ and positively correlated with lactic acid, propionic acid and acetic acid $(p<0.05)$. Furthermore, the bacterial community was significantly correlated with environmental factors. Altitude had a highly positive correlation with the abundance of Stenotrophomonas, Chryseobacterium, and Massilia $(p<0.01)$, while precipitation was negatively correlated with these bacteria. The humidity and average temperature significantly influenced the Lactobacillus and Weissella abundances of fresh whole-plant maize. During the ensiling process, the silages from three regions had similar bacterial dynamic changes, and the Lactobacillus formed and maintained good fermentation characteristics in whole-plant maize silage.

Keywords: whole-plant maize, silage, fermentation quality, microbial community, environmental factor

\section{INTRODUCTION}

Ensiling is a common method for preserving fresh forage and contributes to an uninterrupted supply of forage feedstuff to ruminant animals (Pahlow et al., 2003). Lactic acid bacteria (LAB) are the most important beneficial bacteria in the process of ensiling fermentation (Zhu et al., 2010), which results in organic acids with water-soluble carbohydrate (WSC) as fermentation substrate under anaerobic conditions to reduce $\mathrm{pH}$ value for achieving the purpose of longterm preservation of silage (Keshri et al., 2018). It is well established that LAB regularly relate 
to silage fermentation belong to the genera Enterococcus, Lactobacillus, Lactococcus, Leuconostoc, Pediococcus, Streptococcus, and Weissella (Pang et al., 2011; Ni et al., 2018; Yang et al., 2019). The quality of silage mainly depends on the composition and abundance of microbial communities during ensiling (Kung et al., 2018; Zi et al., 2021a). Whole-plant maize silage has a better absorption rate and higher nutritional value than other silages, and is the most common feed for ruminants worldwide (Khan et al., 2015; Zhang et al., 2019). Various silage microbial compositions have been found in different forages (Guo et al., 2018; Xu et al., 2019; Yuan et al., 2019). In addition, for maize ensiling, previous studies have reported that Lactobacillus was the dominant contributors during ensiling and subsequent exposure to air (Lin et al., 1992; Zhou et al., 2016; Hu et al., 2018). Generally, the composition of microorganisms changes greatly before and after ensiling (Sepehri and Sarrafzadeh, 2019). Therefore, it is of great significance to further study the microbial diversity changes in silage for understanding the whole fermentation process and finding the root cause of fermentation quality changes.

As previously mentioned, uncontrollable climatic conditions affect silage fermentation, microorganisms and aerobic stability (Bernardes et al., 2018; Guan et al., 2018). Ensiling at high temperatures reduces both the lactic acid (LA) concentration and aerobic stability (Ashbell et al., 2002). Moreover, it has been reported that temperature affects the bacterial diversity and fermentation quality of silage (Wang et al., 2019; Li et al., 2021). Epiphytic bacterial communities in fresh forage depends mainly on geographical location, climate, and cutting (Guo et al., 2018; Yang et al., 2019). Cai et al. (1999) studied the microorganisms attached to the surface of corn, sorghum, alfalfa and Italian ryegrass collected from the same place and found that there were very few Pediococcus attached to the surface of sorghum and ryegrass and few Lactobacillus attached to the surface of alfalfa. The community of epiphytic bacteria in corn material has been shown to be affected by rainfall and humidity, and the microbial community during ensiling has been shown to be affected by temperature (Guan et al., 2018).

The composition of the epiphytic community is an important factor of silage quality and changes in the microbial community during fermentation (Gharechahi et al., 2017). Nevertheless, the effect of the environment on the epiphytic community of wholeplant maize silage has rarely been reported. We hypothesized that the succession characteristics of whole-plant maize silage are different in different areas. Therefore, this study aimed to evaluate the correlation between bacterial communities and sampling area environmental factors (altitude, precipitation, temperature, and humidity) and then to examine the dynamic changes in microbial community diversity and fermentation quality during the ensiling of whole-plant maize.

\section{MATERIALS AND METHODS}

\section{Study Sites and Sample Collection}

Whole-plant maize was planted in Ziyun County $(\mathrm{Z})\left(106^{\circ} 10^{\prime} \mathrm{E}\right.$, $25^{\circ} 37^{\prime} \mathrm{N}$, altitude $\left.840 \mathrm{~m}\right)$, Guanling County (G) $\left(105^{\circ} 24^{\prime} \mathrm{E}\right.$, $25^{\circ} 57^{\prime} \mathrm{N}$, altitude $\left.1350 \mathrm{~m}\right)$, and Weining County (W) $\left(104^{\circ} 16^{\prime} \mathrm{E}\right.$, $26^{\circ} 55^{\prime} \mathrm{N}$, altitude $2230 \mathrm{~m}$ ). The monthly changes of temperature, precipitation and humidity in the three regions in 2019 are shown in Figure 1. The variety of maize was Qingfeng No. 4. The samples were planted on February 25, 2019; March 28, 2019; and April 2, 2019 in Ziyun, Guanling, and Weining, respectively. Samples were collected at the dough stage according to local tradition on July 31, 2019; September 12, 2019; and September 18,2019 . Instantly, the materials were collected and transported in ice boxes and stored at $-80^{\circ} \mathrm{C}$ before use. Another part of the collected materials was chopped to approximately $2 \mathrm{~cm}$ by a hand paper cutter. After mixing thoroughly, the material was vacuumpacked into plastic bags. Each bag contained approximately $500 \mathrm{~g}$ of fresh matter. A total of 54 bags (three treatments $\times$ six ensiling durations $\times$ three replicates) were prepared and stored at normal temperature $\left(25-30^{\circ} \mathrm{C}\right)$, and the fermentation time of all samples was approximately 45 days. Samples were used to determine the chemical composition, fermentation quality and microbial community on days $0,2,5,10,20$, and 45 .

\section{Chemical and Fermentation Profile Analyses}

Specimens were determined by drying the samples in a forced air oven at $65^{\circ} \mathrm{C}$ for $72 \mathrm{~h}$ and passed through a $1.0 \mathrm{~mm}$ sieve before the chemical assay. The contents of dry matter (DM) and crude protein $(\mathrm{CP})$ were measured according to previously published study (AOAC, 2000). The WSC content was determined by colorimetric after-reaction with anthrone reagent (Turula et al., 2010). The neutral detergent fiber (NDF) and acid detergent fiber (ADF) were analyzed using a previously established method (Van Soest et al., 1991). To measure fermentation quality, $20 \mathrm{~g}$ samples were suspended in $180 \mathrm{~mL}$ of distilled water overnight at $4^{\circ} \mathrm{C}$ and filtered through four layers of cheesecloth. Then, the filtrates were used to determine the $\mathrm{pH}$ value and ammonia- $\mathrm{N}\left(\mathrm{NH}_{3}-\mathrm{N}\right)$ and organic acid contents. The $\mathrm{pH}$, lactic acid (LA), acetic acid (AA), propionic acid (PA), butyric acid (BA), ammonia-N (AN), and total nitrogen $(\mathrm{TN})$ concentrations were measured as previously established (Li M. et al., 2019).

\section{Bacterial Community Analysis}

The DNA extraction was operated using the HiPure Soil DNA extraction kit (Magen, Guangzhou, China) according to the manufacturer's instructions. The $16 \mathrm{~S}$ rDNA V5-V7 region of the ribosomal RNA gene were amplified by $\mathrm{PCR}\left(94^{\circ} \mathrm{C}\right.$ for $2 \mathrm{~min}$, followed by 30 cycles at $98^{\circ} \mathrm{C}$ for $10 \mathrm{~s}, 62^{\circ} \mathrm{C}$ for $30 \mathrm{~s}$, and $68^{\circ} \mathrm{C}$ for $30 \mathrm{~s}$ and a final extension at $68^{\circ} \mathrm{C}$ for $5 \mathrm{~min}$ ) with primers 799F (AACMGGATTAGATACCCKG) and 1193R (ACGTCATCCCCACCTTCC) (Logue et al., 2016). Amplicons were extracted from 2\% agarose gels and purified using the AxyPrep DNA Gel Extraction Kit (Axygen Biosciences, Union City, CA, United States) according to the manufacturer's instructions and quantified using ABI StepOnePlus Real-Time PCR System (Life Technologies, Foster City, United States). Purified amplicons were pooled in equimolar and paired-end sequenced $(2 \times 250)$ on an Illumina platform according to the standard protocols. 

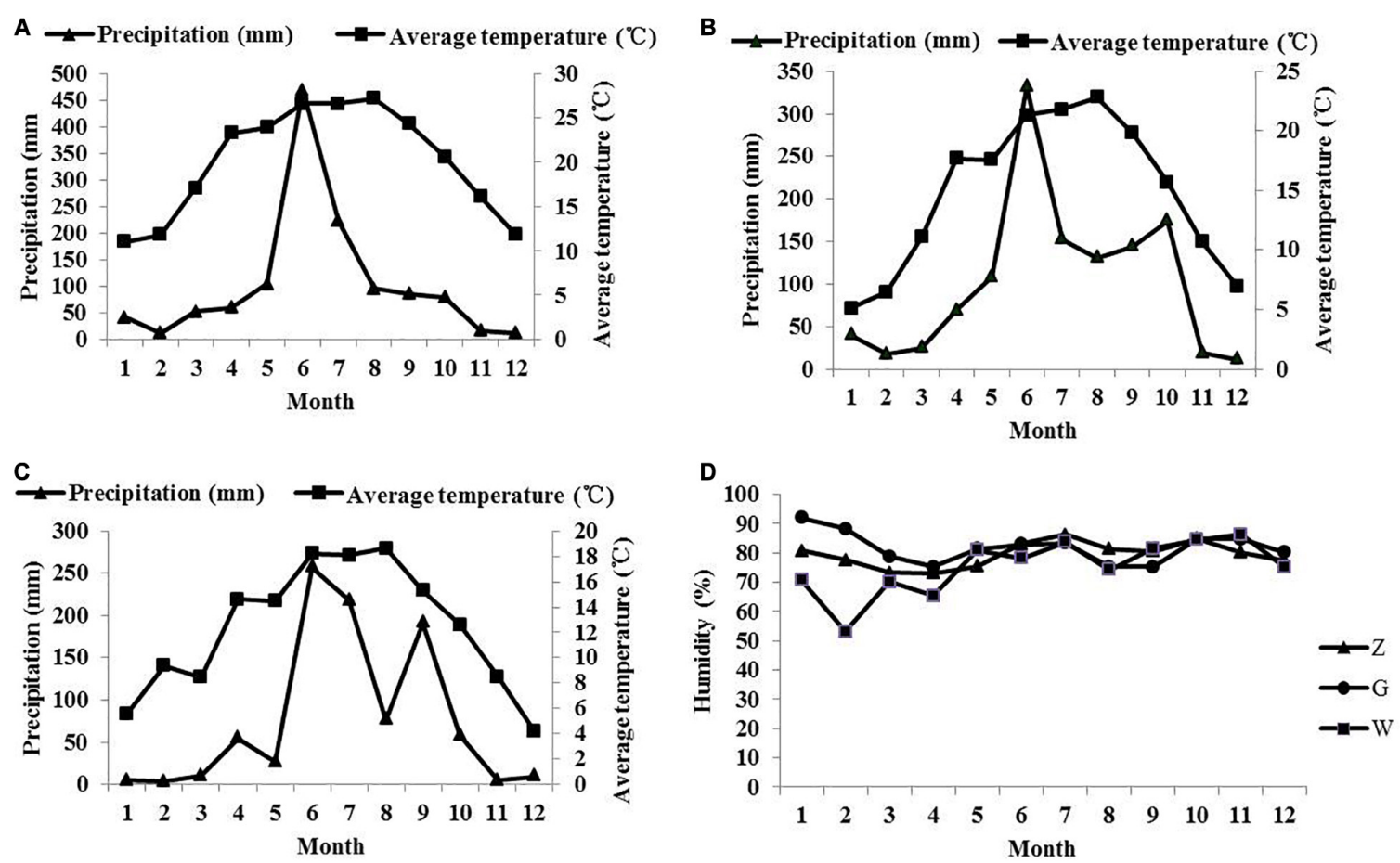

FIGURE 1 | The monthly changes of temperature and precipitation in the area of Ziyun (A), Guanling (B), and Weining (C) in 2019, and monthly humidity changes in three regions (D).

Tag assembly was carried out using filtered reads according to the following principles: the overlap between paired-end reads should be more than 10-bp and have less than a $2 \%$ mismatch. The unique tags were obtained by removal of redundant tags using MOTHUR software (Schloss et al., 2009). The effective tags were clustered into operational taxonomic units (OTUs) of $\geq 97 \%$ similarity using UPARSE (version 9.2.64) pipeline. Diversity metrics were determined using the core-diversity plug-in within QIIME (Callahan et al., 2016). The microbial diversity within an individual sample was assessed using the following alpha diversity indices: the Chao1 richness estimator and Shannon diversity index. Beta diversity was analyzed to assess the structural variation of microbiota across specimens, and then principal component analysis (PCA) was conducted (Vázquez-Baeza et al., 2013). The relative abundances of different bacterial communities at the phylum and genus levels were also analyzed. Pearson correlation coefficient between environmental factors and species was calculated in $\mathrm{R}$ project psych package (version 1.8.4). The heat map function of the $\mathrm{R}$ software and genus information for the Whole-plant silages were used to generate a heat map. Environmental factors during corn growth and fermentation quality after silage were selected for Spearman correlation analysis with bacterial community. The data were analyzed using the free online platform of Omicshare tools.

\section{Statistical Analyses}

The statistical analyses of two-way ANOVA were performed using SPSS 20.0. Duncan's HSD test was employed to determine the differences in the treatment means, where significant differences were declared at $P<0.05$, and the data are expressed as the mean and the standard error of the mean (SEM).

\section{RESULTS}

\section{Chemical Analysis of Whole-Plant Maize Ensiling}

The changes in nutritional components during different regions of ensiling are shown in Table 1. The DM contents of all maize raw materials ranged from 268.6 to $303.3 \mathrm{~g} / \mathrm{kg}$, while the highest $\mathrm{DM}$ content was $303.3 \mathrm{~g} / \mathrm{kg}$ in the $\mathrm{W}$ group $(P<0.05)$, and the lowest DM content was $268.6 \mathrm{~g} / \mathrm{kg}$ in the G group $(P<0.05)$. The content of DM in each group decreased with increasing fermentation time and was in the order of $\mathrm{W}>\mathrm{Z}>\mathrm{G}$ samples at any stage of fermentation. The content of $\mathrm{CP}$ in the $\mathrm{Z}$ and $G$ groups was lower than that in the $W$ group on days 5 and $10(P<0.05)$, while that in the $\mathrm{Z}$ group was lower than that in the $\mathrm{G}$ and $\mathrm{W}$ groups on day $45(P<0.05)$. The WSC content of each group decreased significantly throughout the fermentation process. The contents of $\mathrm{NDF}$ and $\mathrm{ADF}$ in the $\mathrm{Z}$ group were significantly higher than those in the other groups at any stage of fermentation, and they showed a similar decreasing trend with the extension of fermentation time. Moreover, the contents of $\mathrm{NDF}$ and ADF in the G group were lower than those in the other groups on day $45(P<0.05)$. The ensiling time $(\mathrm{D})$ and treatment (T) significantly affected the chemical composition $(P<0.001)$. 
TABLE 1 | Chemical composition of whole-plant maize silage in different regions.

\begin{tabular}{|c|c|c|c|c|c|c|c|c|c|c|c|}
\hline \multirow[t]{2}{*}{ Item } & \multirow[t]{2}{*}{ Treatment } & \multicolumn{6}{|c|}{ Ensiling days } & \multirow[t]{2}{*}{ SEM } & \multicolumn{3}{|c|}{$P$-value } \\
\hline & & 0 & 2 & 5 & 10 & 20 & 45 & & D & $\mathbf{T}$ & $\mathbf{D} \times \mathbf{T}$ \\
\hline \multirow[t]{3}{*}{ Dry matter (g/kg FW) } & Z & $274.1 \mathrm{Ba}$ & 268.6Bb & $262.0 \mathrm{Bc}$ & 254.9Bd & $254.4 \mathrm{Bd}$ & 250.9Be & 0.36 & 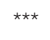 & 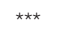 & 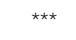 \\
\hline & $G$ & 268.6Ca & $261.7 \mathrm{Cb}$ & $254.5 \mathrm{Cc}$ & $252.6 \mathrm{Cd}$ & $250.7 \mathrm{Ce}$ & 248.6Cf & & & & \\
\hline & W & 303.3Aa & 293.6Ab & 292.1Ac & $274.8 \mathrm{Ad}$ & 264.7Ae & 260.6Af & & & & \\
\hline \multirow{3}{*}{$\begin{array}{l}\text { Water-soluble } \\
\text { carbohydrate (g/kg DM) }\end{array}$} & Z & 86.9Aa & 66.0Ab & 59.0Ac & 42.6Ad & 32.9Ae & $25.2 \mathrm{Af}$ & 0.42 & 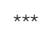 & 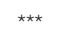 & $\star \star \star \star ~$ \\
\hline & $G$ & $78.9 \mathrm{Ba}$ & $58.4 \mathrm{Bb}$ & 48.7Bc & $40.1 \mathrm{Bd}$ & 33.3Ae & 22.6Bf & & & & \\
\hline & W & $72.0 \mathrm{Ca}$ & $51.4 \mathrm{Cb}$ & $39.7 \mathrm{Cc}$ & $35.4 \mathrm{Cd}$ & $31.5 \mathrm{Be}$ & 21.3Bf & & & & \\
\hline \multirow{3}{*}{$\begin{array}{l}\text { Crude protein }(\mathrm{g} / \mathrm{kg} \\
\text { DM) }\end{array}$} & Z & $74.3 \mathrm{Cb}$ & 71.3Bb & $74.0 \mathrm{Cb}$ & 83.1Ba & $72.9 \mathrm{Cb}$ & $72.5 \mathrm{Cb}$ & 0.74 & 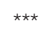 & 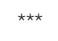 & 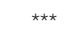 \\
\hline & $\mathrm{G}$ & $84.5 \mathrm{Aa}$ & 81.8Ab & $78.5 \mathrm{Bc}$ & $76.6 \mathrm{Cd}$ & $79.1 \mathrm{Bc}$ & $78.7 \mathrm{Ac}$ & & & & \\
\hline & W & $78.4 \mathrm{Bc}$ & 73.7Bd & 83.0Ab & $90.1 \mathrm{Aa}$ & 89.0Aa & $74.2 \mathrm{Bd}$ & & & & \\
\hline \multirow[t]{3}{*}{ Starch (g/kg DM) } & Z & $267.9 \mathrm{Ca}$ & $262.0 \mathrm{Ab}$ & $259.4 \mathrm{Bc}$ & 258.7Bc & 255.6Bd & 240.8Be & 1.17 & $\star \star \star *$ & $\star \star \star *$ & 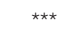 \\
\hline & $\mathrm{G}$ & $275.0 \mathrm{Ba}$ & 252.0Bbc & $252.9 \mathrm{Cb}$ & 250.6Ccd & $248.7 \mathrm{Cd}$ & 244.1Be & & & & \\
\hline & W & 296.2Aa & $260.8 \mathrm{Ac}$ & $272.4 \mathrm{Ab}$ & 275.3Ab & $276.1 \mathrm{Ab}$ & $275.1 A b$ & & & & \\
\hline \multirow{3}{*}{$\begin{array}{l}\text { Neutral detergent fiber } \\
\text { (g/kg DM) }\end{array}$} & Z & 527.1Aa & 525.7Aa & 522.4Aa & $515.8 \mathrm{Ab}$ & 511.0Ab & 475.0Ac & 1.73 & 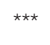 & 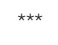 & $\star * \star *$ \\
\hline & $\mathrm{G}$ & 504.1Ba & 496.5Bb & 495.0Bb & $488.5 \mathrm{Bc}$ & 476.0Bd & 456.2Be & & & & \\
\hline & W & 477.3Ca & $461.5 \mathrm{Cb}$ & $457.8 \mathrm{Cb}$ & 444.0Cc & $439.7 \mathrm{Cd}$ & $437.1 \mathrm{Cd}$ & & & & \\
\hline \multirow{3}{*}{$\begin{array}{l}\text { Acid detergent fiber } \\
(\mathrm{g} / \mathrm{kg} \mathrm{DM})\end{array}$} & Z & 257.9Aa & $255.4 \mathrm{Ab}$ & 252.9Ac & $250.2 \mathrm{Ad}$ & 248.6Ae & 246.9Af & 0.64 & 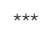 & 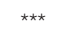 & $\star * \star *$ \\
\hline & $G$ & $250.7 \mathrm{Ba}$ & 244.3Bb & $236.4 \mathrm{Bc}$ & 226.6Cd & $222.4 \mathrm{Ce}$ & 207.3Cf & & & & \\
\hline & W & $244.3 \mathrm{Ca}$ & $237.4 \mathrm{Cb}$ & $232.4 \mathrm{Cc}$ & 229.5Bd & 227.4Be & 225.4Bf & & & & \\
\hline
\end{tabular}

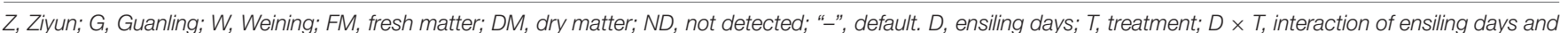
treatment; SEM, standard error of means; Means with different letters in the same row (a-f) or column $(A-C)$ differ $(P<0.05)$, ${ }^{* * *} P<0.001$.

The results also showed a significant interaction between $\mathrm{D}$ and $\mathrm{T}$ for the contents of DM, WSC, NDF, and $\operatorname{ADF}(P<0.001)$.

\section{The Fermentation Property of Whole-Plant Maize During Ensiling}

Table 2 illustrates the fermentation quality of whole-plant maize silage in different regions. The $\mathrm{pH}$ value of each group decreased significantly on the second day of fermentation $(P<0.05)$, all of which were below 4.2. Moreover, the highest and lowest $\mathrm{pH}$ appeared in the $\mathrm{G}$ group and the $\mathrm{W}$ group on day $45(P<0.05)$, respectively. The LA content of each group increased significantly during fermentation, and the highest LA content was found in the $\mathrm{W}$ group on day $45(P<0.05)$. The contents of AA and PA in each group gradually increased with prolonged ensiling, and the contents in the $\mathrm{Z}$ group were lower than those in the other groups on day $45(P<0.05)$. The contents of BA were not detected in all silages. The contents of AN/TN in all groups were dramatically increased $(P<0.05)$ during fermentation, within lower than $5 \%$. Moreover, $\mathrm{pH}, \mathrm{AA}, \mathrm{LA}, \mathrm{PA}$, and AN/TN were interactively influenced by treatment and ensiling days $(p<0.001)$.

\section{Microbial Diversity of Whole-Plant Maize During Ensiling}

The bacterial alpha diversities of the silages were evaluated by the Chaol and Shannon indexes (Figures 2A,B). The bacterial diversity increased with the extension of fermentation time in the
Z group. However, the bacterial diversity of silages in the G group and the $\mathrm{W}$ group was richer after 2 days of fermentation.

The relative abundances of bacterial communities at the phylum and genus levels were presented in Figures 3, 4. As seen in Figure 3, Proteobacteria and Firmicutes were the top two phyla during the process of ensiling in the three regions. Lactobacillus, Weissella, and Acetobacter were the most dominant genera in all maize silages. Figure 4A shows the abundance of Proteobacteria was the most abundant phylum in the G group, exceeding 95\% in raw materials. The dominant bacteria on the surface of maize in the $\mathrm{Z}$ and $\mathrm{W}$ groups were Firmicutes, with relative abundances of 90.55 and $71.70 \%$, respectively, and Proteobacteria had relative abundances of 9.22 and $27.04 \%$, respectively. At the genus level, Weissella and Lactobacillus were found in large amounts in the Z and $\mathrm{W}$ groups, while no obvious dominant bacteria were found in the G group of raw materials.

All the groups were dominated by Firmicutes and Proteobacteria during ensiling at the phylum level. The Proteobacteria abundance decreased while that of Firmicutes increased rapidly and became the dominant phylum with increasing fermentation time. At the genus level, the most dominant bacterial genera were Lactobacillus and Weissella in the samples during the ensiling process. After ensiling, Lactobacillus was the dominant microbial genus, and its relative abundance exceeded $70 \%$. The Lactobacillus abundance significantly increased with the extension of fermentation time, while those of Weissella and Acinetobacter significantly decreased 
TABLE 2 | Fermentation quality of whole-plant maize silage in different regions.

\begin{tabular}{|c|c|c|c|c|c|c|c|c|c|c|c|}
\hline \multirow[t]{2}{*}{ Item } & \multirow[t]{2}{*}{ Treatment } & \multicolumn{6}{|c|}{ Ensiling days } & \multirow[t]{2}{*}{ SEM } & \multicolumn{3}{|c|}{$P$-value } \\
\hline & & 0 & 2 & 5 & 10 & 20 & 45 & & D & $\mathbf{T}$ & $\mathbf{D} \times \mathbf{T}$ \\
\hline \multirow[t]{3}{*}{$\mathrm{pH}$} & Z & $5.60 A a$ & $3.76 \mathrm{Cc}$ & $3.72 \mathrm{Bc}$ & 3.67Bd & $3.62 \mathrm{Ce}$ & $3.80 \mathrm{Bb}$ & 0.015 & 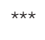 & 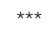 & 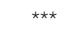 \\
\hline & $\mathrm{G}$ & 5.59Aa & $4.03 \mathrm{Ab}$ & $3.87 \mathrm{Ac}$ & $3.83 \mathrm{Ac}$ & $3.78 \mathrm{Ad}$ & $3.88 \mathrm{Ac}$ & & & & \\
\hline & W & 5.56Aa & $3.91 \mathrm{Bb}$ & $3.73 \mathrm{Bc}$ & $3.67 \mathrm{Bd}$ & 3.66Bd & $3.52 \mathrm{Ce}$ & & & & \\
\hline \multirow[t]{3}{*}{ Lactic acid (g/kg DM) } & Z & ND & $31.5 \mathrm{Ad}$ & 33.3Ac & $34.4 \mathrm{Ab}$ & 36.0Aa & 29.2Be & 0.179 & $\star \star \star *$ & $\star \star \star \star ~$ & 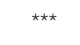 \\
\hline & $\mathrm{G}$ & ND & $22.5 \mathrm{Ce}$ & $26.0 \mathrm{Bc}$ & $27.7 \mathrm{Bb}$ & $30.2 \mathrm{Ca}$ & $23.5 \mathrm{Cd}$ & & & & \\
\hline & W & ND & 24.9Bd & $33.2 \mathrm{Ac}$ & $34.3 \mathrm{Ab}$ & $34.8 \mathrm{Bb}$ & 36.1Aa & & & & \\
\hline \multirow[t]{3}{*}{ Acetic acid (g/kg DM) } & Z & ND & 1.6Ae & $2.4 \mathrm{Ad}$ & $2.7 \mathrm{Ac}$ & $3.4 \mathrm{Ab}$ & $4.5 \mathrm{Ca}$ & 0.067 & 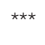 & $\star \star \star \star ~$ & 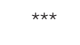 \\
\hline & G & ND & 1.3Be & $1.9 \mathrm{Bd}$ & $2.3 \mathrm{Bc}$ & $2.9 \mathrm{Bb}$ & 5.5Aa & & & & \\
\hline & W & ND & 1.7Ad & $2.4 \mathrm{Ac}$ & $2.6 \mathrm{Ac}$ & $3.7 \mathrm{Ab}$ & $4.9 \mathrm{Ba}$ & & & & \\
\hline \multirow{3}{*}{$\begin{array}{l}\text { Propionic acid (g/kg } \\
\text { DM) }\end{array}$} & Z & ND & $0.8 \mathrm{Cd}$ & $1.1 \mathrm{Bc}$ & 1.4Bb & 1.6Bb & $1.9 \mathrm{Ba}$ & 0.058 & $\star \star \star *$ & $\star \star \star \star ~$ & 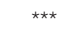 \\
\hline & $\mathrm{G}$ & ND & 1.1Bd & $1.9 \mathrm{Ac}$ & $2.1 \mathrm{Ac}$ & $2.3 \mathrm{Ab}$ & $2.7 \mathrm{Aa}$ & & & & \\
\hline & W & ND & $1.4 \mathrm{Ae}$ & $1.7 \mathrm{Ad}$ & $1.9 A c$ & 2.2Ab & $2.5 \mathrm{Aa}$ & & & & \\
\hline \multirow[t]{3}{*}{ Butyric acid (g/kg DM) } & Z & ND & ND & ND & ND & ND & ND & - & - & - & - \\
\hline & G & ND & ND & ND & ND & ND & ND & & & & \\
\hline & W & ND & ND & ND & ND & ND & ND & & & & \\
\hline \multirow{3}{*}{$\begin{array}{l}\text { Ammonia-N ( } \mathrm{g} / \mathrm{kg} \text { total } \\
\mathrm{N})\end{array}$} & Z & 15.9Be & 19.5Bd & $23.0 \mathrm{Bc}$ & $23.7 \mathrm{Bc}$ & $27.0 \mathrm{Bb}$ & $34.4 \mathrm{Ba}$ & 0.393 & 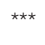 & 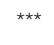 & 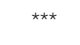 \\
\hline & $G$ & $15.5 \mathrm{Bf}$ & $22.5 \mathrm{Ae}$ & 25.1Ad & $30.9 A c$ & $34.8 \mathrm{Ab}$ & 41.7Aa & & & & \\
\hline & W & $20.1 \mathrm{Ae}$ & 23.0Ad & 23.9Bcd & $24.8 \mathrm{Bc}$ & $26.5 \mathrm{Bb}$ & $31.9 \mathrm{Ca}$ & & & & \\
\hline
\end{tabular}

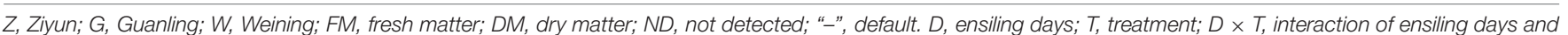
treatment; SEM, standard error of means; Means with different letters in the same row (a-f) or column $(A-C)$ differ $(P<0.05)$, ${ }^{* * *} P<0.001$.

or disappeared in the subsequent period. The relative abundance of Acetobacter in each group decreased with the process of ensiling. By 45 days, the relative abundance of Acetobacter in each group decreased to below $1 \%$. In addition, Pantoea and Stenotrophomonas existed in the whole corn silage period of all three regions.

\section{Correlation Analysis Between Bacterial Communities and Environmental Factors}

The association analysis between bacterial abundance and environmental factors is shown in Figure 5. Negative correlations were observed between the average temperature and the relative abundance of the Lactobacillus (-0.73), Sphingomonas (-0.67), Stenotrophomonas (-0.74), Allorhizobium-NeorhizobiumPararhizobium-Rhizobium (-0.92), Chryseobacterium (-0.75), and Massilia (-0.71). Altitude was associated with increased abundance of Rahnella, Stenotrophomonas, Chryseobacterium, Massilia $(p<0.05)$, Serratia, and Allorhizobium-NeorhizobiumPararhizobium-Rhizobium $(p<0.01)$. The level of precipitation was associated with decreased abundance of Rahnella, Serratia $(p<0.01)$ and Stenotrophomonas, AllorhizobiumNeorhizobium-Pararhizobium-Rhizobium, Chryseobacterium and Massilia $(p<0.05)$. Humidity was associated with increased abundance of Weissella, Lactobacillus, Stenotrophomonas, Chryseobacterium, Massilia $(p<0.05)$, and AllorhizobiumNeorhizobium-Pararhizobium-Rhizobium $(p<0.001$ ), while it was associated with decreased abundance of Escherichia-Shigella $(p<0.05)$.

\section{Correlation Analysis of Bacterial Community With Fermentation Products}

The association analysis between bacterial abundance and fermentation indexes is shown in Figure 6. Specifically, the $\mathrm{pH}$ value was associated with decreased abundance of Lactobacillus $(p<0.01)$. The LA concentration was associated with increased abundance of Lactobacillus ( $p<0.05$ ), while it was negatively correlated with that of Pseudomonas and Massilia $(p<0.05)$. The contents of AA and PA were associated with increased abundance of Lactobacillus ( $p<0.001$ ), while AA concentration was negatively correlated with the abundance of Acetobacter and Pseudomonas $(p<0.01)$ and Pantonea $(p<0.05)$, PA concentration was associated with decreased abundance of Acetobacter, Pseudomonas and Lysinibacillus $(p<0.01)$ and Weissella, Gluconobacter, and Oceanobacillus $(p<0.05)$. Finally, the positive correlations have been observed between AN/TN concentrations and Lactobacillus $(p<0.01)$ and Herbaspirillum $(p<0.05)$, while AN/TN concentrations was associated with decreased abundance of Acetobacter, Rahnella, Pseudomonas, Lysinibacillus, and Pantoea $(p<0.05)$.

\section{DISCUSSION}

\section{Nutritional Characteristics of Whole-Plant Maize During Ensiling}

The expected DM content for good silage is 30 35\% (Guyader et al., 2018). The DM content in each group decreased with the 


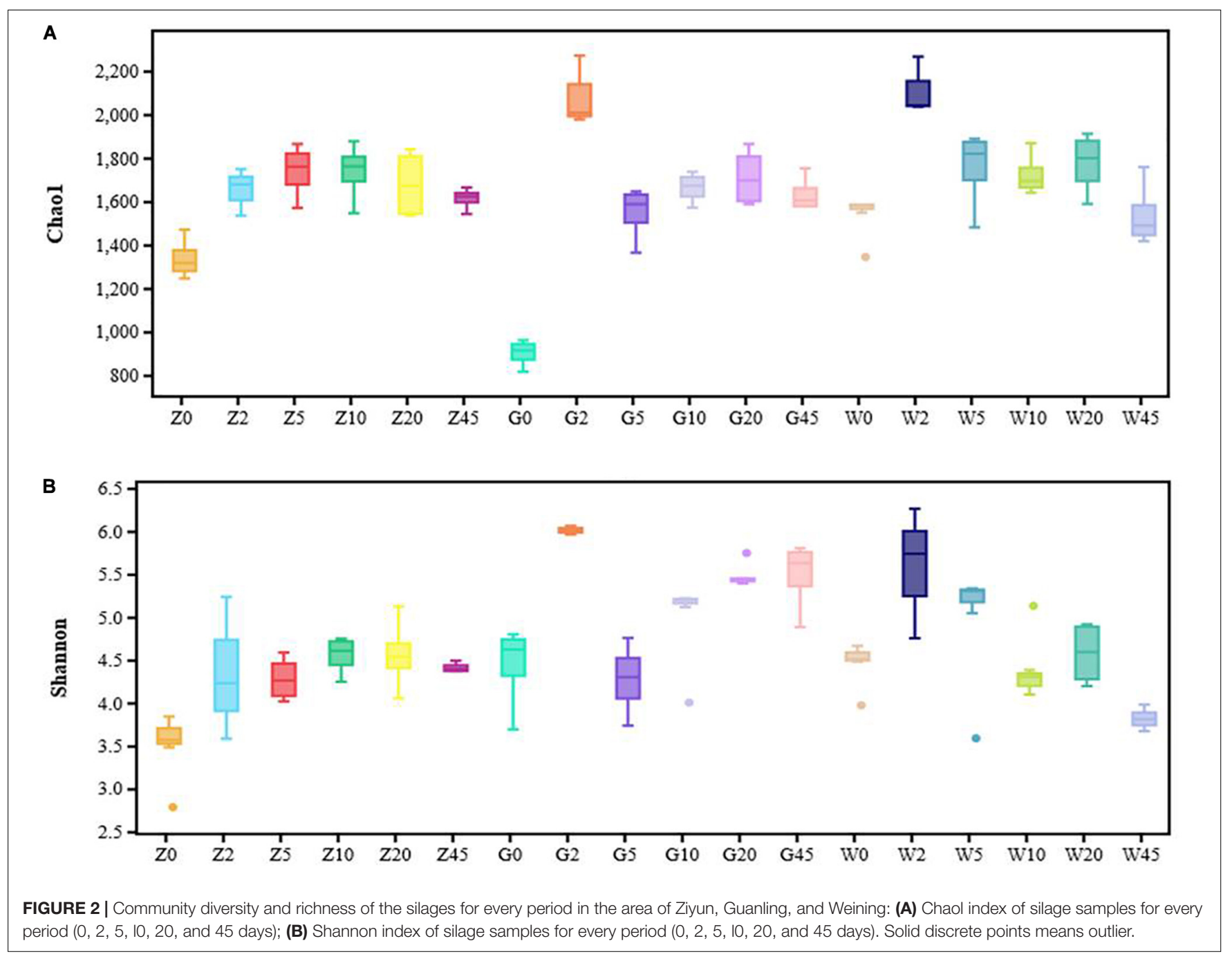

extension of fermentation time, which was mainly due to the WSC being consumed by LAB and other microorganisms for fermentation (Hu et al., 2009). The different CP contents of raw materials may be related to cultivation and fertilization (Miao et al., 2006). CP is one of the main nutritional components of silage, and the degradation of protein will affect the nutritional value of pastures. The lost nitrogen can only meet the nutritional needs of livestock by supplementing protein feed in the diet, thus increasing the breeding cost (Bilal, 2009). In this study, the CP content of the $\mathrm{Z}$ and $\mathrm{G}$ groups increased on the 10th and 20th days, respectively, while that of the $\mathrm{W}$ group increased on the 5 th and 10th days of fermentation, which may be due to the decrease in DM content (Zhang et al., 2018). In addition, when the $\mathrm{pH}$ was low, some bacteria composed of protein could not grow and reproduce in the fermentation process and became a part of the feed, which also increased the content of CP (Bilal, 2009). On the other hand, the loss in CP was relatively small due to good fermentation.

The WSC content decreased significantly throughout the fermentation process, and the loss rate of each group reached $70 \%$. As the substrate of silage fermentation, the
WSC content will be decomposed by LAB to produce LA (Moselhy et al., 2015). The content of ADF and NDF affects the chewing time of ruminants and indirectly affects feed digestibility in domestic animals (Jang et al., 2017). In the present study, the contents of NDF and ADF in each group decreased with increasing fermentation time, which indicated that silage fermentation had a certain degradation effect on the fiber components of whole-plant maize, thus improving the digestibility of silage.

\section{The Fermentation Property of Whole-Plant Maize During Ensiling}

The $\mathrm{pH}$ value of silage is an important index to evaluate the success of silage, and well-fermented silage should have a $\mathrm{pH}$ of 3.8 4.2 (Kung et al., 2018). The low pH value ensures that harmful bacteria are inhibited and finally contributes to the good fermentation of whole-plant maize (Keshri et al., 2018). The $\mathrm{pH}$ was less than 4.0 and reached the lowest point at 20 days in all the silages except for that in the $\mathrm{W}$ group, which agreed with the results of a previous study (Sun et al., 2021). 

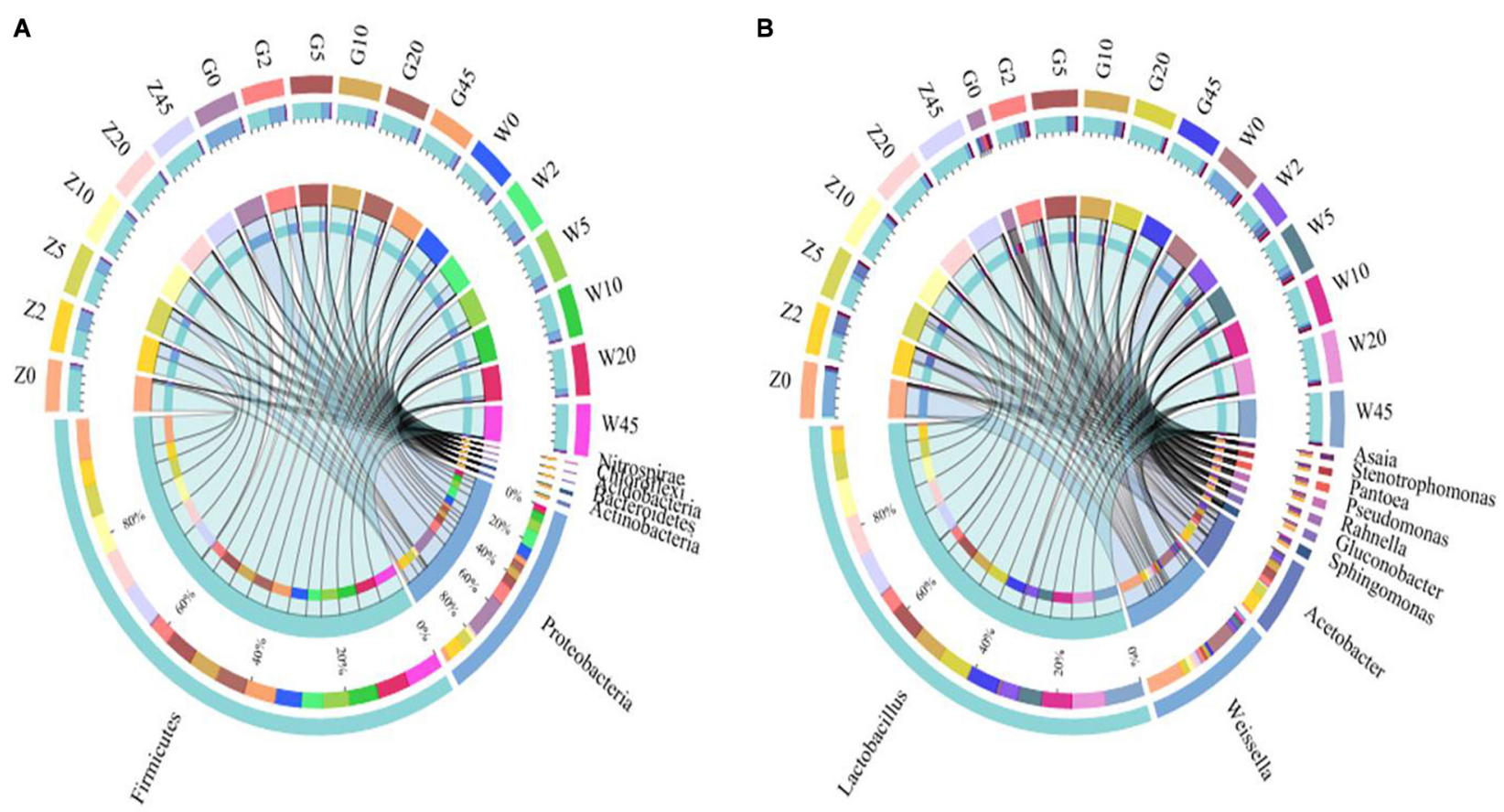

FIGURE 3 | Circos map of bacterial communities at the phylum (A) and genus levels (B) for whole-plant maize silage.
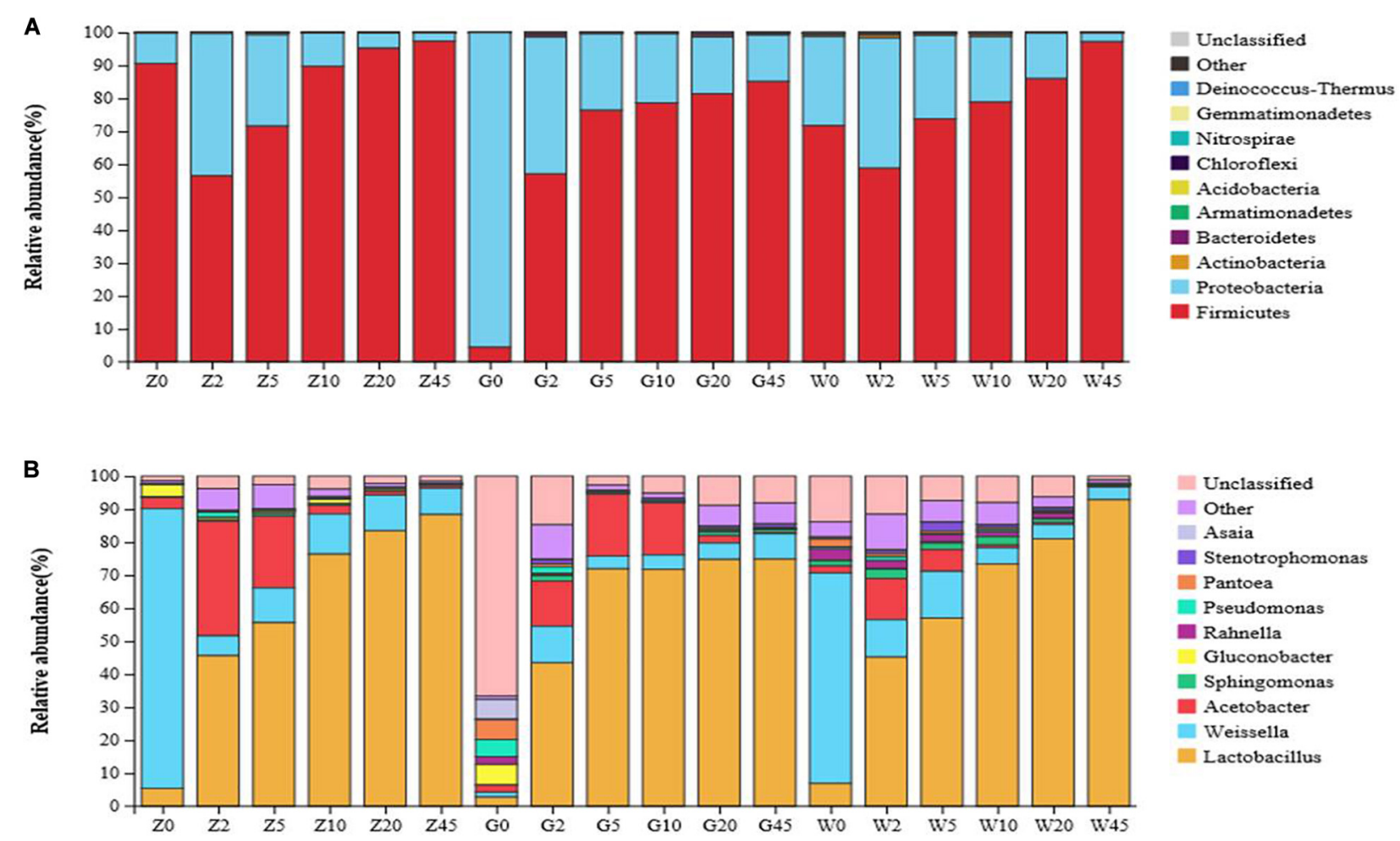

FIGURE 4 | The relative abundance of bacteria community proportions at the phylum $\mathbf{( A )}$ and genus (B) level across the treatments (as a percentage of the total sequence). 


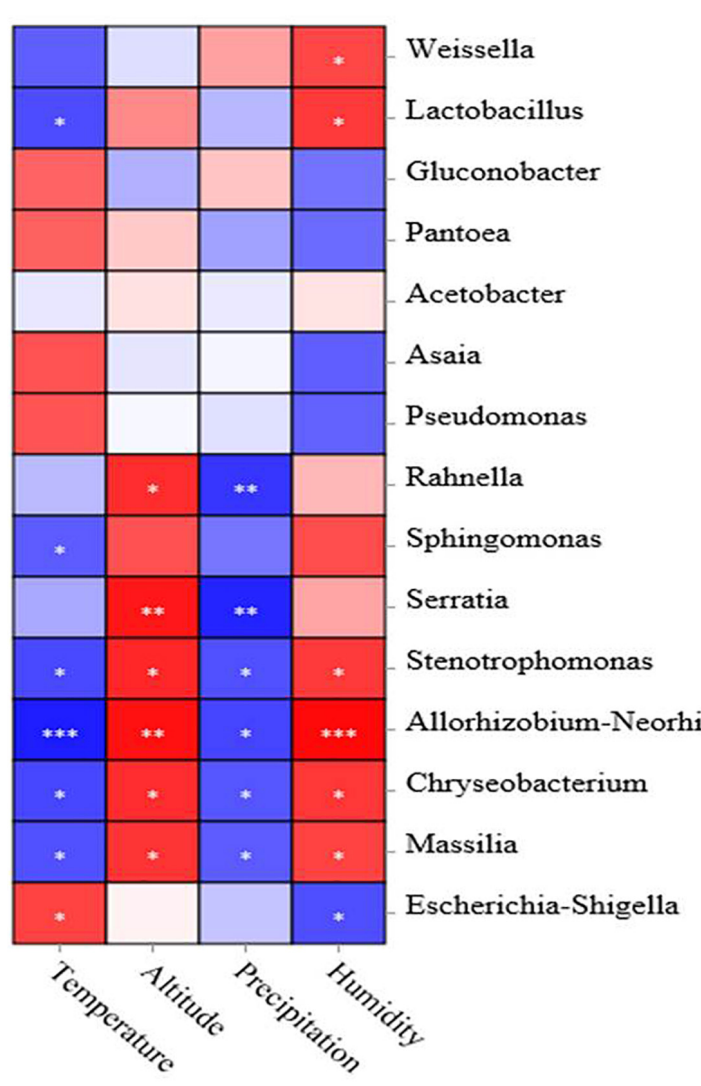

FIGURE 5 | Correlation analysis of the bacterial community with environmental factors. Positive correlations are shown in red, and negative correlations are shown in blue. '* , **, and ${ }^{* * *}$ ' represents $P<0.05, P<0.01$, and $P<0.001$, respectively.

According to the fermentation mode, LA fermentation can be divided into homofermentative and heterofermentative types (Guo et al., 2018). Homofermentation mainly produces LA, whereas heterofermentation also produces $\mathrm{AA}$, ethanol and $\mathrm{CO}_{2}$ in addition to LA (Pahlow et al., 2003). In this study, LAB grew rapidly and produced enough LA in each group, which inhibited the growth and reproduction of harmful microorganisms. With increasing LA content, homofermentative LAB are inhibited, while heterofermentative $\mathrm{LAB}$ begin to dominate due to the stronger tolerance to $\mathrm{AA}$ and $\mathrm{pH}$ value, and fermentation gradually changes from homofermentative $\mathrm{LAB}$ fermentation to heterofermentative LAB fermentation (Shao et al., 2002). The AA content of each group gradually increased with increasing fermentation time. In addition, when the silage is fermented to a certain extent and the $\mathrm{pH}$ is low, the fermentation of LAB will also be inhibited. At the same time, some anaerobic microorganisms that may exist in silage begin to decompose LA and produce other organic acids, such as AA and PA, which leads to a decrease in LA content (Shao et al., 2002). In this study, with the extension of fermentation time, the LA content decreased and the AA and PA contents increased gradually in the G group, which indicated that the type of fermentation was heterofermentative. The contents of LA and AA were relatively high, and the ammonia nitrogen content was within a limited range. These indexes showed the excellent fermentation quality of all the silages. BA is a product produced by decomposing protein, glucose and LA by spoilage bacteria and BA bacteria, respectively (Addah et al., 2012). It has been reported that $\mathrm{BA}$ content $>5 \mathrm{~g} / \mathrm{kg} \mathrm{DM}$ affects the palatability of feed and reduces the feed intake by livestock (Muck, 2010). During the whole fermentation process, BA was not detected in any group.

During the ensiling process, the ammonia nitrogen is mainly produced by the degradation of protein by plant enzymes and the utilization of protein and amino acids by microbial decomposition (Kung et al., 2018). In general, the ammonia$\mathrm{N}$ content is recommended to be less than $5 \%$ for maize silage (Zhang et al., 2016). The high ammonia-N content indicates that proteolysis occurred to a deep extent during ensiling $(\mathrm{Mu}$ et al., 2021). In the present study, the content of AN/TN in each group was lower than $5 \%$, indicating that harmful bacteria were effectively inhibited.

\section{Microbial Diversity of Whole-Plant Maize During Ensiling}

The microbe numbers and species composition are varied with different silage materials or ensiling processes (Khota et al., 2016). Various epiphytic bacterial communities in raw 


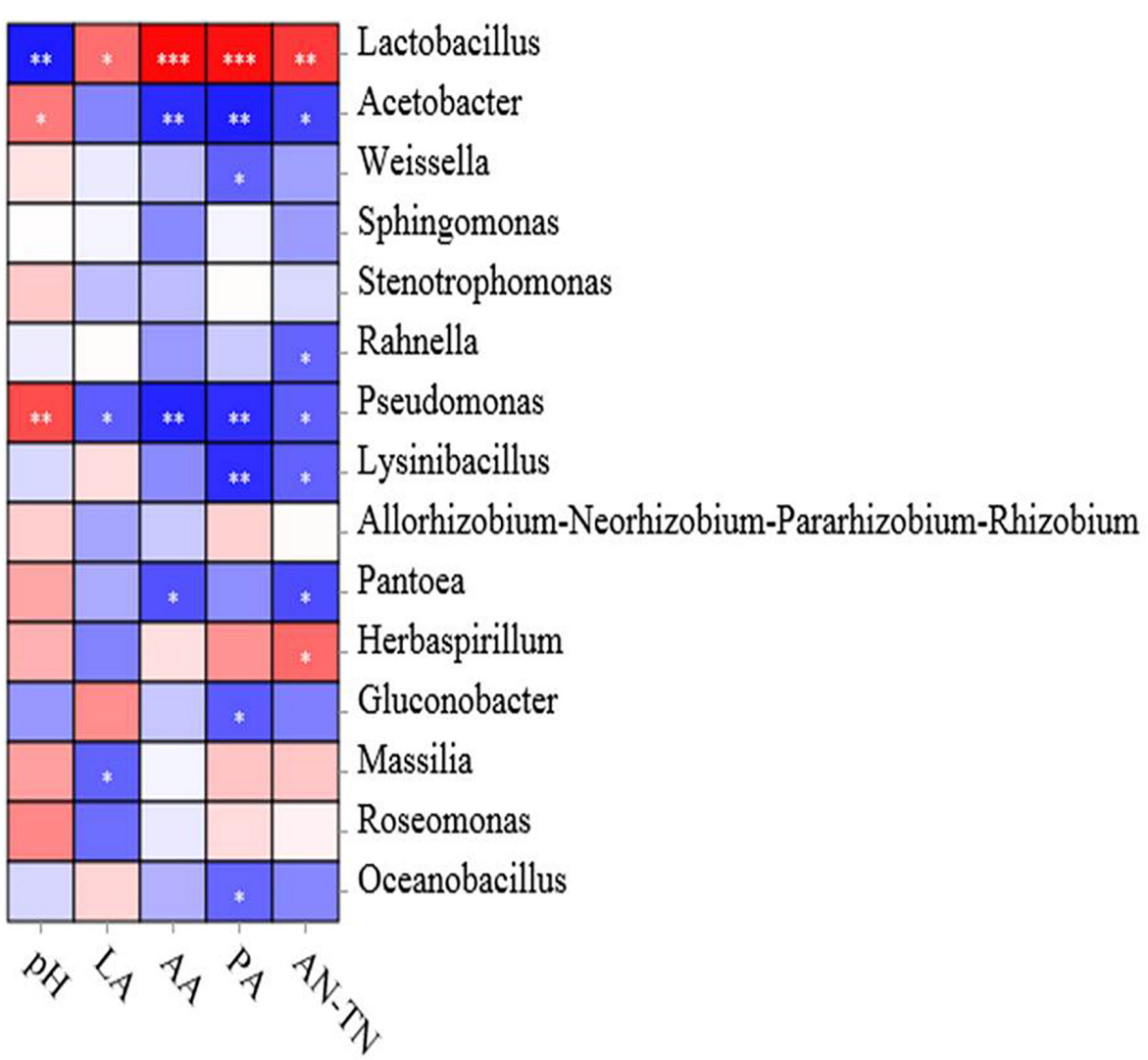

FIGURE 6 | Relationships of fermentation characteristics with silage bacterial community at the genus level. Positive correlations are shown in red, and negative correlations are shown in blue. '*, **, and ${ }^{* * *}$ ' represent $P<0.05, P<0.01$, and $P<0.001$, respectively.

materials might originate from unique growth environments (McGarvey et al., 2013). Gharechahi et al. (2017) reported a special bacterial community in whole-plant corn from different geographical locations. In this study, the differences at the species level in the epiphytic microorganisms of the Wholeplant fresh samples from the three areas were observed. The sampling locations in three areas belong to a subtropical monsoon climate and are close to each other. The phylum-level bacteria mainly attached to the surface of silage maize in the three regions were Firmicutes and Proteobacteria. Additionally, the main LAB genus in fresh forages was Weissella. This indicated that Weissella might play a major role in the early stage of fermentation (Sun et al., 2021). This genus is a selective anaerobic bacterium, which converts water-soluble sugars into LA and AA in the early stage of silage fermentation (Cai et al., 1998). In the current study, Weissella with low abundance was detected in silages during the ensiling process (Figure 4), which might lead to relatively high AA content in all silages (Table 2).

The nature of silage is due to complex microbial succession (Yang et al., 2019), in which bacteria play a key role (Li P. et al., 2019). In this study, the abundance of Firmicutes increased rapidly and became the dominant phylum during ensiling. This observation might be explained by the fact that the growth of Firmicutes is related to the low $\mathrm{pH}$ and anaerobic conditions formed during ensiling (Wang et al., 2019; Zhang et al., 2019). Although Lactobacillus was usually not the dominant bacteria in fresh corn of the $\mathrm{Z}$ group, it began to dominate at 2 days of ensiling. This observation suggested that the LAB count in the raw materials is enough to ensure the fermentation quality of the final silage. Lactobacillus, Lactococcus, Weissella, and Enterococcus are common LA-producing bacteria in silage, and their abundance changes are closely related to the quality of silage (Ni et al., 2018). Generally, LA-producing cocci are the dominant LAB. These initiate LA fermentation during the early stages of ensiling, whereby Lactobacillus will grow rapidly into the dominant bacteria (Liu et al., 2019). This result suggested that Lactobacillus was an important genus for silage fermentation during ensiling. Many studies have shown the dominance of Lactobacillus in ensiled corn silages (Li and Nishino, 2011; Ogunade et al., 2017) due to its desirable functions during ensiling (Li et al., 2017; Liu et al., 2019). The study showed that Lactobacillus and Weissella were the only LAB with high abundance in the whole-plant maize silage process in different regions, which was consistent with the research of Ogunade et al. (2017), and the reason for the difference with the research of 
Tohno et al. (2013) and Ni et al. (2017b) may be related to the research materials and locations.

Gluconobacter and Acetobacter were found in minor abundance during the early stages of ensilage. Acetobacter is a kind of AA-producing and nitrogen-fixing bacteria (Kumiko et al., 2001) and may lead to the decline in $\mathrm{pH}$ at the early stage of the ensiling process. Other bacteria, such as Pantoea, Rahnella, and Sphingomonas, were evenly distributed during the ensiling process in lower amounts are consistent with previous studies (Gharechahi et al., 2017; Ni et al., 2017a), and some of them are undesirable in silage (McDonald et al., 1991). Muck (2010) reported that Bacillus, Paenibacillus, Enterobacter, Enterococcus, and Clostridium are the main microorganisms that decompose proteins into ammonia nitrogen and cause protein loss. None of these bacteria were found in the top 10 bacteria regarding relative abundance, which was consistent with the previous results of low AN/TN contents in the present study.

\section{Correlation Analysis Between Bacterial Communities and Environmental Factors}

There are many factors (moisture, WSC, regional factors) that affect the microbiome and influence the fermentation quality of silage (McEniry et al., 2010; Bernardes et al., 2018). Usually, regional factors include temperature, humidity, precipitation, longitude, latitude, and altitude. Previous reports showed that high temperatures and rainfall had detrimental effects on the fermentation process and silage quality (Kim and Adesogan, 2006). In addition, high temperature affected the transformation of microorganisms in corn silage from a homofermentative to a heterofermentative LAB community, which had been previously reported (Guan et al., 2020). Guan et al. (2018) reported that Weissella, Pseudomonas, and Lactobacillus were the main epiphytic bacteria of corn silage in high-temperature and high-humidity areas. Moreover, $\mathrm{Zi}$ et al. (2021b) reported that temperature, humidity, and precipitation affected the fermentation quality of silage through the changes in microbiomes. Epiphytic bacterial communities are highly related to climate (Bernardes et al., 2018). In this study, altitude was positively correlated with the abundance of Stenotrophomonas, Chryseobacterium, and Massilia, while precipitation was negatively correlated with these bacteria. This indicates that precipitation was the factor affecting the epiphytic bacteria of the silage material. The Lactobacillus abundance in fresh maize did not change regularly with increasing altitude, and the reason for the difference may be related to the temperature and precipitation in the three regions. The correlation analysis (Figure 5) showed that the relative abundance of Lactobacillus was negatively correlated with temperature. This also explains why the temperature of the $\mathrm{G}$ group was the highest $\left(21.35^{\circ} \mathrm{C}\right)$, while the relative abundance of attached Lactobacillus was the lowest $(2.75 \%)$. The temperature of the $\mathrm{W}$ group was the lowest $\left(17.32^{\circ} \mathrm{C}\right)$, while the relative abundance of attached Lactobacillus was the highest (63.77\%). Altitude and precipitation influence some microorganisms in silage, but they do not relate to the main bacteria in silage, such as Lactobacillus and Weissella. This shows that when silage enters a completely anaerobic environment, the influence of climate factors on the main microorganisms will become smaller. Cai et al. (1999) reported that a certain amount of LAB in forage will have a great impact on silage fermentation. In this study, Lactobacillus and Weissella were correlated with temperature and humidity, and the most dominant bacterial genera were Lactobacillus and Weissella in the samples during the ensiling process. This result indicated that the main factors affecting the microbial diversity of silages were humidity and average temperature. Environmental factors affect the community of epiphytic bacteria on raw materials, which have a greater impact on the initial stage of silage fermentation (Zi et al., 2021b). We speculate that the influence of environmental factors on the microbial community will decrease during the silage fermentation process, thus reducing its influence on silage quality.

\section{Correlation Analysis of Bacterial Community With Fermentation Products}

Microorganisms affect silage quality through a series of metabolites. For example, Lactobacillus species mainly affect LA production (Guan et al., 2018). In the present study, The Lactobacillus was positively correlated with the LA content, which dominated the bacterial community in the fermentation process and had a negative correlation with $\mathrm{pH}$ in all silages. This result was consistent with the report of Sun et al. (2021). Pseudomonas is an undesirable bacterium that can survive in an anaerobic environment, and its production of biogenic amines leads to the decrease in protein content (Roberson and Firestone, 1992; Dunière et al., 2013). The AN/TN content was negatively correlated with the abundance of Pseudomonas, indicating that the existence of Pseudomonas may contribute to the preservation of protein (Ogunade et al., 2018). Other studies have confirmed these findings, indicating that the fermentation characteristics are highly correlated with the microflora of silage and affect the overall fermentation quality (Ren et al., 2019; Yang et al., 2019).

\section{CONCLUSION}

All of the whole-plant maize silages had satisfactory fermentation quality. The bacterial community of fresh raw material was mainly composed of Weissella and Proteobacteria. Although the bacterial community varied during ensiling, Lactobacillus dominated the ensiling process. Lactobacillus had a negative correlation with $\mathrm{pH}$ in all silages and grew well under low $\mathrm{pH}$ conditions, produced LA during ensiling, and effectively influenced fermentation quality. Altitude and precipitation influenced some specific microorganisms in silage, but they did not affect the main bacteria in silages. The humidity and average temperature significantly influenced the abundances of Lactobacillus and Weissella of fresh whole-plant maize and had a greater impact on the whole fermentation process.

\section{DATA AVAILABILITY STATEMENT}

The original contributions presented in the study are included in the article/supplementary material, further inquiries can be directed to the corresponding author/s. 


\section{AUTHOR CONTRIBUTIONS}

$\mathrm{JH}$ and $\mathrm{CC}$ contributed to conception and design of the study. $\mathrm{LL}, \mathrm{SD}$, and CW performed the statistical analysis. YH wrote the manuscript and interpretation of data. All the authors read and contributed to the manuscript.

\section{REFERENCES}

Addah, W., Baah, J., Okine, E. K., and McAllister, T. A. (2012). A third-generation esterase inoculant alters fermentation pattern and improves aerobic stability of barley silage and the efficiency of body weight gain of growing feedlot cattle. J. Anim. Sci. 90, 1541-1552. doi: 10.2527/jas.2011-4085

AOAC (2000). Official Methods of Analysis, 17th Edn. Washington, DC: Association of Official Analytical Chemists.

Ashbell, G., Weinberg, Z. G., Hen, Y., and Filya, I. (2002). The effects of temperature on the aerobic stability of wheat and corn silages. J. Ind. Microb. Biotechnol. 28, 261-263. doi: 10.1038/SJ/JIM/7000237

Bernardes, T. F., Daniel, J. L. P., Adesogan, A. T., McAllister, T. A., Drouin, P., Nussio, L. G., et al. (2018). Silage review: unique challenges of silages made in hot and cold regions. J. Dairy Sci. 101, 4001-4019. doi: 10.3168/jds.2017-13703

Bilal, M. Q. (2009). Effect of molasses and com silage addves on the characteristics of mott dwarf elephant grass silage at different fermentation periods. Pakistan Vet. J. 29, 395-396.

Cai, Y. M., Kumai, S., Ogawa, M., Benno, Y., and Nakase, T. (1999). Characterization and identification of Pediococcus species isolated from forage crops and their application for silage preparation. Appl. Environ. Microbiol. 65, 2901-2906. doi: 10.1128/AEM.65.7.2901-2906.1999

Cai, Y., Benno, Y., Ogawa, M., Ohmomo, S., Kumai, S., and Nakase, T. (1998). Influence of Lactobacillus spp. from an inoculant and of weissella and Leuconostoc spp. from forage crops on silage fermentation. Appl. Environ. Microbiol. 64, 2982-2987. doi: 10.1128/AEM.64.8.2982-2987.1998

Callahan, B. J., Mcmurdie, P. J., Rosen, M. J., Han, A. W., Johnson, A. J. A., and Holmes, S. P. (2016). DADA2: high-resolution sample inference from illumine amplicon data. Nat. Methods 13, 581-583. doi: 10.1038/nmeth.3869

Dunière, L., Sindou, J., Chaucheyras-Durand, F., Chevallier, I., and Thévenot Sergentet, D. (2013). Silage processing and strategies to prevent persistence of undesirable microorganisms. Anim. Feed Sci. Technol. 182, 1-15. doi: 10.1016/ j.anifeedsci.2013.04.006

Gharechahi, J., Kharazian, Z. A., Sarikhan, S., Jouzani, G. S., Aghdasi, M., and Salekdeh, G. H. (2017). The dynamics of the bacterial communities developed in maize silage. Microb. Biotechnol. 10, 1663-1676. doi: 10.1111/1751-7915.12751

Guan, H., Shuai, Y., Yan, Y., Ran, Q., Wang, X., Li, D., et al. (2020). Microbial community and fermentation dynamics of corn silage prepared with heatresistant lactic acid bacteria in a hot environment. Microorganisms 8:719. doi: 10.3390/microorganisms8050719

Guan, H., Yan, Y., Li, X., Li, X., Shuai, Y., Feng, G., et al. (2018). Microbial communities and natural fermentation of corn silages prepared with farm bunker-silo in Southwest China. Bioresour. Technol. 265, 282-290.

Guo, X. S., Ke, W. C., Ding, W. R., Ding, L. M., Xu, D. M., Wang, W. W., et al. (2018). Profiling of metabolome and bacterial community dynamics in ensiled Medicago sativa inoculated without or with Lactobacillus plantarum or Lactobacillus buchneri. Sci. Rep. 8, 357-366. doi: 10.1038/s41598-017-18348-0

Guyader, J., Baron, V., and Beauchemin, K. (2018). Corn forage yield and quality for silage in short growing season areas of the Canadian prairies. Agronomy 8, 164-176. doi: 10.3390/agronomy8090164

Hu, W., Schmidt, R. J., Mcdonell, E. E., Klingerman, C. M., and Kung, L. Jr. (2009). The effect of Lactobacillus buchneri 40788 or Lactobacillus plantarum MTD1 on the fermentation and aerobic stability of corn silages ensiled at two dry matter contents. J. Dairy Sci. 92, 3907-3914. doi: 10.3168/jds.2008-1788

Hu, Z., Chang, J., Yu, J., Li, S., and Niu, H. (2018). Diversity of bacterial community during ensiling and subsequent exposure to air in whole-plant maize silage. Asian Australas. J. Anim. Sci. 31, 1464-1473. doi: 10.5713/ajas.17.0860

Jang, S. Y., Kim, E. K., Park, J. H., Tang, Y. J. M., Ding, Y. L., and Kim, W. H. (2017). Effects of physically effective neutral detergent fiber content on dry matter intake, digestibility, and chewing activity in Korean native goats (Capra

\section{FUNDING}

This work was supported by the Science and Technology Support project of Guizhou Province [(2021)-043] and the Talent Base of Grassland Ecological Animal Husbandry talent in Guizhou Province (RCJD2018-13).

hircus coreanae) fed with total mixed ration. Asian Australas. J. Anim. Sci. 30, 1405-1409. doi: 10.5713/ajas.16.0868

Keshri, J., Chen, Y., Pinto, R., Kroupitski, Y., Weinberg, Z. G., and Sela, S. (2018). Microbiome dynamics during ensiling of corn with and without Lactobacillus plantarum inoculant. Appl. Microbiol. Biot. 102, 4025-4037.

Khan, N. A., Yu, P., Ali, M., Cone, J. W., and Hendriks, W. H. (2015). Nutritive value of maize silage in relation to dairy cow performance and milk quality. J. Sci. Food Agr. 95, 238-252. doi: 10.1002/jsfa.6703

Khota, W., Pholsen, S., Higgs, D., and Cai, Y. (2016). Natural lactic acid bacteria population of tropical grasses and their fermentation factor analysis of silage prepared with cellulase and inoculant. J. Dairy Sci. 99, 9768-9781. doi: 10.3168/ jds.2016-11180

Kim, S. C., and Adesogan, A. T. (2006). Influence of ensiling temperature, simulated rainfall, and delayed sealing on fermentation characteristics and aerobic stability of corn silage. J. Dairy Sci. 89, 3122-3132. doi: 10.3168/jds. s0022-0302(06)72586-3

Kumiko, N., Taniguchi, M., Ujike, S., Ishihara, N., Mori, H., Ono, H., et al. (2001). Characterization of acetic acid bacteria in traditional acetic acid fermentation of rice vinegar (komesu) and unpolished rice vinegar (kurosu) produced in Japan. Appl. Environ. Microbiol. 67, 986-990. doi: 10.1128/AEM.67.2.986-990.2001

Kung, L. Jr., Shaver, R. D., Grant, R. J., and Schmidt, R. J. (2018). Silage review: interpretation of chemical, microbial, and organoleptic components of silages. J. Dairy Sci. 101, 4020-4033. doi: 10.3168/jds.2017-13909

Li, L., Yuan, Z., Sun, Y., Kong, X., Dong, P., and Zhang, J. (2017). A reused method for molasses-processed wastewater: effect on silage quality and anaerobic digestion performance of Pennisetum purpereum. Bioresour. Technol. 241, 1003-1011. doi: 10.1016/j.biortech.2017.04.117

Li, M., Zi, X., Tang, J., Zhou, H., and Cai, Y. (2019). Silage fermentation, chemical composition and ruminal degradation of king grass, cassava foliage and their mixture. Grassland Sci. 64, 210-215. doi: 10.1111/grs.12235

Li, P., Zhang, Y., Gou, W., Cheng, Q., Bai, S., and Cai, Y. (2019). Silage fermentation and bacterial community of bur clover, annual ryegrass and their mixtures prepared with microbial inoculant and chemical additive. Anim. Feed Sci. Technol. 247, 285-293. doi: 10.1016/j.anifeedsci.2018 .11 .009

Li, X. M., Chen, F., Wang, X. K., Sun, L., Guo, L. N., Xiong, Y., et al. (2021). Impacts of low temperature and ensiling period on the bacterial community of oat silage by SMRT. Microorganisms 9:274. doi: 10.3390/MICROORGANISMS9020274

Li, Y., and Nishino, N. (2011). Monitoring the bacterial community of maize silage stored in a bunker silo inoculated with Enterococcus faecium. Lactobacillus plantarum and Lactobacillus buchneri. J. Appl. Microbiol. 110, 1561-1570. doi: 10.1111/j.1365-2672.2011.05010.x

Lin, C., Bolsen, K. K., Brent, B. E., and Daniel, Y. C. F. (1992). Epiphytic lactic acid bacteria succession during the pre-ensiling and ensiling periods of alfalfa and maize. J. Appl. Microbio. 73, 375-387.

Liu, B., Huan, H., Gu, H., Xu, N., Shen, Q., and Ding, C. (2019). Dynamics of a microbial community during ensiling and upon aerobic exposure inlactic acid bacteria inoculation-treated and untreated barley silages. Bioresour. Technol. 273, 212-219. doi: 10.1016/j.biortech.2018.10.041

Logue, J. B., Stedmon, C. A., Kellerman, A. M., Nielsen, N. J., and Andersson, A. F. (2016). Experimental insights into the importance of aquatic bacterial community composition to the degradation of dissolved organic matter. ISME J. 10, 533-545. doi: 10.1038/ismej.2015.131

McDonald, P., Henderson, A. R., and Heron, S. J. E. (1991). The Biochemistry of Silage. Version, 2th Edn. Marlow: Chalcombe Publications.

McEniry, J., O’Kiely, P., Clipson, N., Forristal, P., and Doyle, E. (2010). Assessing the impact of various ensilage factors on the fermentation of grass silage using conventional culture and bacterial community analysis techniques. J. Appl. Microbiol. 108, 1584-1593. doi: 10.1111/j.1365-2672.2009.04557.x 
McGarvey, J., Franco, R., Palumbo, J., Hnasko, R., Stanker, L., and Mitloehner, F. (2013). Bacterial population dynamics during the ensiling of Medicago sativa (alfalfa) and subsequent exposure to air. J. Appl. Microbiol. 114, 1661-1670. doi: $10.1111 /$ jam.12179

Miao, Y., Mulla, D. J., Robert, P. C., and Hernandez, J. A. (2006). Within-field variation in corn yield and grain quality responses to nitrogen fertilization and hybrid selection. Agron. J. 98, 129-140. doi: 10.2134/agronj2005.0120

Moselhy, M. A., Borba, J. P., and Borba, A. E. S. (2015). Improving the nutritive value, in vitro digestibility and aerobic stability of Hedychium gardnerianum silage through application of additives at ensiling time. Anim. Feed Sci. Technol. 206, 8-18. doi: 10.1016/j.anifeedsci.2015.05.001

Mu, L., Xie, Z., Hu, L., Chen, G., and Zhang, Z. (2021). Lactobacillus plantarum and molasses alter dynamic chemical composition, microbial community, and aerobic stability of mixed (amaranth and rice straw) silage. J. Sci. Food. Agr. 101, 5225-5235. doi: 10.1002/JSFA.11171

Muck, R. (2010). Silage microbiology and its control through additives. Rev. Bras. Zootec. 39, 183-191. doi: 10.1590/S1516-35982010001300021

Ni, K. K., Wang, F. F., Zhu, B. G., Yang, J. X., and Zhou, G. A. (2017b). Effects of lactic acid bacteria and molasses additives on the microbial community and fermentation quality of soybean silage. Bioresour. Technol. 238, 706-715. doi: 10.1016/j.biortech.2017.04.055

Ni, K. K., Minh, T. T., and Tu, T. T. (2017a). Comparative microbiota assessment of wilted Italian ryegrass, whole crop corn, and wilted alfalfa silage using denaturing gradient gel electrophoresis and next-generation sequencing. Appl. Microbiol. Biotechnol. 101, 1385-1394. doi: 10.1007/s00253-016-7900-2

Ni, K., Zhao, J., Zhu, B., Su, R., Pan, Y., Ma, J., et al. (2018). Assessing the fermentation quality and microbial community of the mixed silage of forage soybean with crop corn or sorghum. Bioresour. Technol. 265, 563-567. doi: 10.1016/j.biortech.2018.05.097

Ogunade, I. M., Jiang, Y., Kim, D. H., Cervantes, A. A. P., Arriola, K. G., Vyas, D., et al. (2017). Fate of E. coli O157:H7 and bacterial diversity in corn silage contaminated with the pathogen and treated with chemical or microbial additives. J. Dairy Sci. 100, 1780-1794. doi: 10.3168/jds.2016-11745

Ogunade, I. M., Jiang, Y., Pech Cervantes, A. A., Kim, D. H., Oliveira, A. S., Vyas, D., et al. (2018). Bacterial diversity and composition of alfalfa silage as analyzed by Illumina MiSeq sequencing: effects of Escherichia coli O157:H7 and silage additives. J. Dairy Sci. 101, 2048-2059. doi: 10.3168/jds.2017-12876

Pahlow, G., Muck, R. E., Driehuis, F., Oude Elferink, S. J. W. H., and Spoelstra, S. F. (2003). "Microbiology of ensiling," in Silage Science and Technology, eds D. R. Buxton, R. E. Muck, and J. H. Harrison (Madison, WI: American Society of Agronomy), 31-93.doi: 10.2134/agronmonogr42.c2

Pang, H., Qin, G., Tan, Z., Li, Z., Wang, Y., and Cai, Y. (2011). Natural populations of lactic acid bacteria associated with silage fermentation as determined by phenotype, $16 \mathrm{~S}$ ribosomal RNA and recA gene analysis. Syst. Appl. Microbiol. 34, 235-241. doi: 10.1016/j.syapm.2010.10.003

Ren, F., He, R., Zhou, X., Gu, Q., Xia, Z., Liang, M., et al. (2019). Dynamic changes in fermentation profiles and bacterial community composition during sugarcane top silage fermentation: a preliminary study. Bioresour. Technol. 285:121315. doi: 10.1016/j.biortech.2019.121315

Roberson, E. B., and Firestone, M. K. (1992). Relationship between desiccation and exopolysaccharide production in a soil Pseudomonas sp. Appl. Environ. Microb. 58, 1284-1291. doi: 10.1128/AEM.58.4.1284-1291. 1992

Schloss, P. D., Westcott, S. L., Ryabin, T., Hall, J. R., Hartmann, M., Hollister, E. B., et al. (2009). Introducing mothur: open-source, platform-independent, community-supported software for describing and comparing microbial communities. Appl. Environ. Microbiol. 75, 7537-7541. doi: 10.1128/aem. 01541-09

Sepehri, A., and Sarrafzadeh, M. (2019). Activity enhancement of ammoniaoxidizing bacteria and nitrite-oxidizing bacteria in activated sludge process: metabolite reduction and $\mathrm{CO} 2$ mitigation intensification process. Appl. Water Sci. 9:131. doi: 10.1007/s13201-019-1017-6

Shao, T., Ohba, N., Shimojo, M., and Masuda, Y. (2002). Dynamics of early fermentation of Italian ryegrass (Lolium multiflorum Lam.)silage. Asian Aust. J. Anim. Sci. 15, 1606-1610.

Sun, L., Bai, C., Xu, H., Na, N., Jiang, Y., Yin, G., et al. (2021). Succession of bacterial community during the initial aerobic,intense fermentation, and stable phases of whole-plant corn silages treated with lactic acid bacteria suspensions prepared from other silages. Front. Microbiol. 12:655095. doi: 10.3389/FMICB. 2021.655095

Tohno, M., Kitahara, M., Irisawa, T., Masuda, T., Uegaki, R., Ohkuma, M., et al. (2013). Lactobacillus silagei sp. nov. Isolated from orchardgrass silage. Int. J. Syst. Evol. Microbiol. 63, 4613-4618. doi: 10.1099/ijs.0.053124-0

Turula, V. E. J., Gore, T., Singh, S., and Arumugham, R. G. (2010). Automation of the anthrone assay for carbohydrate concentration determinations. Anal. Chem. 82, 1786-1792. doi: 10.1021/ac902664x

Van Soest, P. J., Robertson, J. B., and Lewis, B. A. (1991). Methods for dietary fiber neutral detergent fiber, and nonstarch polysaccharides in relation to animal nutrition. J. Dairy Sci. 74, 3583-3597. doi: 10.3168/jds.s0022-0302(91)78551-2

Vázquez-Baeza, Y., Meg, P., and Antonio, G. (2013). EMPeror: a tool for visualizing high-throughput microbial community data. GigaScience 2:16.

Wang, Y., Chen, X., Wang, C., He, L., Zhou, W., Yang, F., et al. (2019). The bacterial community and fermentation quality of mulberry (Morus alba) leaf silage with or without Lactobacillus casei and sucrose. Bioresour. Technol. 293, 122059. doi: 10.1016/j.biortech.2019.122059

Xu, D., Ding, W., Ke, W., Li, F., Zhang, P., and Guo, X. (2019). Modulation of metabolome and bacterial community in whole crop corn silage by inoculating homofermentative Lactobacillus plantarum and Heterofermentative Lactobacillus buchneri. Front. Microbiol. 9:3299. doi: 10.3389/FMICB.2018.03299

Yang, L., Yuan, X., Li, J., Dong, Z., and Shao, T. (2019). Dynamics of microbial community and fermentation quality during ensiling of sterile and nonsterile alfalfa with or without Lactobacillus plantarum inoculant. Bioresour. Technol. 275, 280-287. doi: 10.1016/j.biortech.2018.12.067

Yuan, X. J., Li, J. F., Dong, Z. H., and Shao, T. (2019). The reconstitution mechanism of napier grass microiota during the ensiling of alfalfa and their contributions to fermentation quality of silage. Bioresour. Technol. 297:122391. doi: 10.1016/j.biortech.2019.122391

Zhang, L., Zhou, X., Gu, Q., Liang, M., Mu, S., Zhou, B., et al. (2019). Analysis of the correlation between bacteria and fungi in sugarcane tops silage prior to and after aerobic exposure. Bioresour. Technol. 291:121835.

Zhang, Q., Yu, Z., Wang, X., and Tian, J. (2018). Effects of inoculants and environmental temperature on fermentation quality and bacterial diversity of alfalfa silage. Anim. Sci. J. 89, 1085-1092. doi: 10.1111/asj.12961

Zhang, Y., Yang, J., Wang, J., Zheng, N., Li, S., Zhao, S., et al. (2016). Progress assessment of chemical indicators of silage. Chinese J. Anim. Husbandry. 52, 37-42.

Zhou, Y., Drouin, P., and Lafreniere, C. (2016). Effect of temperature $\left(5-25^{\circ} \mathrm{C}\right)$ on epiphytic lactic acid bacteria populations and fermentation of whole-plant corn silage. J. Appl. Microbiol. 121, 657-671. doi: 10.1111/jam.13198

Zhu, M. F., Xie, Y. N., Li, S. J., Chen, X. W., and Zhao, Z. (2010). Technical measures for improving quality of silage maize in Southern area. Anim. Husb. Feed Sci. 31, 31-34.

Zi, X., Li, M., Chen, Y., Lv, R., Zhou, H., and Tang, J. (2021a). Effects of citric acid and Lactobacillus plantarum on silage quality and bacterial diversity of king grass silage. Front. Microbiol. 12:631096. doi: 10.3389/fmicb.2021.631096

Zi, X., Li, M., Yu, D., Tang, J., Zhou, H., and Chen, Y. (2021b). Natural fermentation quality and bacterial community of 12 pennisetum sinese varieties in Southern China. Front. Microbiol. 12:627820. doi: 10.3389/fmicb.2021.627820

Conflict of Interest: The authors declare that the research was conducted in the absence of any commercial or financial relationships that could be construed as a potential conflict of interest.

Publisher's Note: All claims expressed in this article are solely those of the authors and do not necessarily represent those of their affiliated organizations, or those of the publisher, the editors and the reviewers. Any product that may be evaluated in this article, or claim that may be made by its manufacturer, is not guaranteed or endorsed by the publisher.

Copyright (c) 2021 Huang, Liang, Dai, Wu, Chen and Hao. This is an open-access article distributed under the terms of the Creative Commons Attribution License (CC BY). The use, distribution or reproduction in other forums is permitted, provided the original author(s) and the copyright owner(s) are credited and that the original publication in this journal is cited, in accordance with accepted academic practice. No use, distribution or reproduction is permitted which does not comply with these terms. 